\title{
AFGHANISTAN'S ENERGY AND NATURAL RESOURCES
}

October 1989

Russel1 Balcome-Rawding

Kathryn Cameron Porter

U.S. Department of Energy

1000 Independence Avenue, S.W.

Washington, D.C. 20585 
TABLE OF CONTENTS

Page

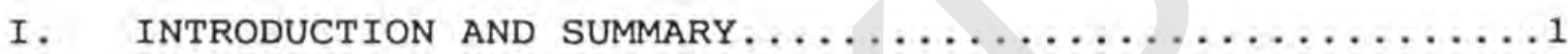

II. HISTORICAL OVERVIEW: Thwarted Opportunities.........3

III. NATURAL RESOURCES: A SurveY of POSSibilities........18

IV. THE FUTURE: Post War Rehabilitation and Reconstruction. .43

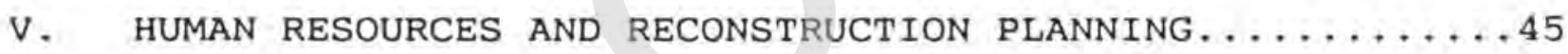

VI. CONCLUSIONS: Future Energy Sources................50

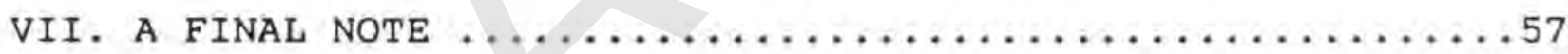




\section{AFGHANISTAN'S ENERGY AND NATURAL RESOURCES}

This study provides a resource perpective from which to better plan the necessary steps toward the viable reconstruction and economic development of post war Afghanistan. The vast availability of natural resources affords the opportunity to formulate a framework upon which Afghanistan can grow and prosper in the future. The paper includes the following sections:

- Historical Overview: Thwarted Opportunities

+ Natural Resources: A Survey of Possibilities

- The Future: Post War Rehabilitation and Reconstruction

- Conclusions: Future Energy Sources 
Information for this report has been developed from a number of sources which include extensive interviews with Afghans in Pakistan, Europe, and the United States who worked in the relevant governmental ministries before the Communist Coup in 1978, the Soviet invasion in 1979, and those who remained in Afghanistan during the war years and have since defected to the Resistance. Their eyewitness accounts and contributions of documentation provide authenticity to the strong case that Afghanistan is far better endowed with energy and mineral resources than has been understood in the past. The contents of this report have been verified by non-classified sources in libraries, archival materials and personal communications. Thanks must also go to Dr. John Shroder of the University of Nebraska who made avallable all of his research which has been so helpful in this report. 


\section{HISTORICAL OVERVIEW: Thwarted Opportunities}

Leon Trotsky's remarks to the Central Committee in 1919:

"The international situation is evidently shaping in such a way that the road to Paris and London lies via the towns in Afghanistan, the Punjab (Pakistan) and Bengal (India)."

The Soviet Union's nine and one half years of occupation of Afghanistan has focused world attention on a country referred to as the Heart of Central Asla. Once a center of trade, and part of the Silk Route to China, Afghanistan in the 20th Century was perceived as an underdeveloped and xenophobic country with little to interest world powers. The Soviet invasion in December 1979 not only caught many unaware, but once again thrust "The Great Game" upon governments who too late had realized the strategic importance of this nation. When Soviet forces had moved 400 miles closer to the Persian Gulf, Afghanistan suddenly became important to many nations, 
The Soviet fallure to subjugate this nation of fiercely independent people culminated in their, withdrawal of troops in February of 1989. The Soviet military may have withdrawn most of their troops, but Soviet interest in the energy resources of Afghanistan remalns and has been solidified with well over two thousand slgned agreements. Soviet Chalrman Mikhail Gorbachev in his speech in Tyumen, Western Siberia on September 6, 1985 stated, "The Party has put forward responsible tasks aimed at the acceleration of the development of our economy, and I shall tell you flatly that in order to be able to perform them, the country must have at its disposal the necessary resources of both oil and gas... oil and gas will always be the object of our constant concern."

Energy concerns have been evidenced by Soviet intrusion into Afghanistan. It is significant that every year since Soviet control began to tighten on Afghanistan, including the time before the actual invasion, the information on the country's mineral resources had, in fact, demonstrably, decreased. Material used by the U.S. Department of Interior to compile its annual world wide Minerals Yearbook is collected, to a great extent, through the U.N., in which, of course, the U.S.S.R. participates. Each year since 1975, the information on Afghanistan included in this publication has not increased with Soviet exploration, but decreased. In 1984, the Yearbook referred to reported information on Afghanistan as "sparse." 
Although it was believed that an energy data base on Afghanistan was sparse and scattered, many experts had begun to compile statistics and from that began to reevaluate the reasons behind the invasion. Experts from Great Britain, France, Germany, Sweden, Italy, Japan, Canada, and the United States have contributed to geological resource information which substantiates the abundance of Afghanistan's natural resources. It is now believed that far more than simple security of its southern border and access to Persian Gulf oil drove the Soviets southward. As Dr. John F. Shroder points out in Afghan Resources and Soviet Exploitation in Afghanistan, The Great Game, there are two crescent shaped areas in the Eastern hemisphere. One running from North Africa through the Middle East into Central U.S.S.R. contains 748 of the world's proven ofl and gas reserves; the second including central and southern Africa, Afghanistan, and the U.S.S.R's Kazacksh and Yuktia mineral belts contains $61 \%$ of the world's other proven minerals (except coal.) In recent years Soviet activities and that of 1 ts Cuban proxy have been heavily concentrated in these two crescents. Geological surveys of the country initiated by the Soviets over a century ago are well documented.

The first Soviet publication on "Mineral Riches of Afghanistan" appeared in geological literature in 1927. Since 1927, the Soviets have been interested in Afghan mineral 
resources, but in the 1950 's gaining control over Afghan minerals and energy resources became a top priority in Soviet relations. Dr. John F, Shroder, an American geology professor was director of the National Atlas of Afghanistan and a Fulbright lecturer at Kabul Unlversity before the Soviet invasion. In his article, Are the Soviets after Mineral Resources in Geotimes, March, 1987, Shroder states "the Soviets are unlikely to forget resource insecurity was a factor that led the Central and Axis Powers to start both world wars."

Soviet energy insecurity explains the intensifying intrusion into Afghanistan's internal affairs beginning at the end of World War II. In the 40's and 50's, U.S. Geological Survey teams predicted large ofl reserves. O11 was first found in 1950 by Swedish experts at Angot, Saripul of Jowzjan Province. In 1953, Afghanistan was the first non-communist nation to accept Soviet economic aid, but, it was a debt they would never be allowed to repay .

In the late 1950 's, the Afghans turned to France and Sweden for technical assistance in oil development. The Soviets forced both countries out by diplomatic and economic maneuvering. Increasing Soviet involvement into the operations of the Afghan government extended to the Ministry of Mines and Industries. By the end of the 1960 's, Soviet control over Afghanistan's operations included its entire hydrocarbon and mineral industry. 
The Soviets were not initially interested in oil exploration since oll was currently being imported to Afghanistan from the Soviet Union. Energy self-sufficiency would impact negatively on the Soviet export market. Moreover, by keeping tight control of the exploration activities, they could keep the oil reserves in Afghanistan for their future use. Afghan domestic oil needs were manipulated and administered by the Soviets. The Soviets convinced the top levels of the Afghan goverment that gas exports were the most profitable course of action and further pressed their case by arguing that Afghanistan was not endowed with major oil reserves. They emphasized that the reserves in the northern provinces did not justify the construction of a refinery: therefore, they should not pursue oil exploration there.

In 1970, the fourth draft of the Five Year Plan (1971/72 $1976 / 77$ ) of the Royal Kingdom of Afghanistan was in it's final stages. The Afghan government requested an extension of the Soviet constructed natural gas pipeline, which linked the northern provinces to the Soviet Union. The Afghans wanted to link the natural gas plpeline to Kabul and other major cities. The Soviets turned down this request on the technical grounds of "lack of pressure" and "high cost of installing the pipeline." 
The leftist coup by Daoud in 1973 resulted in the removal of most Westerners from any resource development projects. Information on Afghan resources was suppressed, but in the late 1970s, Dr. Shroder learned about extensive Soviet exploration and stated it resulted in "first rate geologic reports and maps and identification of over 1400 mineral showings or occurances as well as 70-odd commercial deposits."

After the Daoud coup, a team of Soviet planners came to Kabul, headed by Mr. Astrovsk1, to draw up the outline for a new development plan for Afghanistan. A seven year plan was drawn up without utilizing natural gas for domestic use. Afghan technocrats complained loudly that their country had an abundance of resources with which their country could be self-sufficient. President Daoud had a personal interest in developing the country and began to follow an independent policy toward that goal. He renewed efforts to find oll throughout the country and Afghan engineers were given a chance to begin exploration and drilling free from Soviet supervision. They reported to him that they were able to find enough to meet Afghanistan's energy needs. Daoud made the decision that Afghan engineers only would continue working in Katawaz but these attempts were later subverted by the Soviets. 
The heavy handed behavior of Soviet exploitation of Afghan resources extended to all energy sectors. For instance, the Afghan government proposed a project to establish a small factory for production of concentrated gas in transportable metal containers, similar to those built in Pakistan and Iran. The Soviets also turned down this project with the claim that Afghan gas was of a light and unstable quality that was impossible to pressurize. In addition, they claimed that it would explode before it could be changed to liquid form. When an Afghan engineer from the Ministry of Mines and Industry argued the matter, the chief of the visiting delegation, Mr. Astrovski, declared the matter closed for "obvious technical reasons."

The Afghans also sought to secure and install a production facility for gas powered thermal power stations in order to meet the needs of the northern and central provinces. The Soviets countered this proposal for energy self sufficiency with their own proposal to import electricity from the Soviet Union to Afghanistan. The Soviets insisted this course of action was economically feasible, and thus began the linkage of the power grids of Afghanistan to those of the Soviet Union. 
In 1975, the Afghan government created by law, the Afghanistan National o1l Company (ANOC) which was to regulate activities of forelgn companies. Among its responsibilities, were development and implemtation of a National Petroleum Law for negotiations with firms for exploration rights and permits, oversight of the firms activities and determination for the best use of indigenous resources. It also provided that all joint ventures with ANOC be $51 \%$. ANOC-owned. These steps would have provided for considerable independence and economic selfdetermination, which obviously would have given the Soviets less control than they wanted and the loss of Afghanistan as a market for Soviet oil.

During the Afghan government's preparation of the 7 year plan for 1976 to 1983 , the Soviets were asked to provide credit for construction of an oil refinery. After a series of discussions, the Soviets finally promised to consider a study for the installation of a 50,000-100,000 ton per annum refinery. The original Afghan proposal called for a 500,000 ton refinery. Letters related to the project were exchanged between the relevant authorities of the two countries throughout 1976 and 1977. The project was stonewalled until the communist coup in 1978. 
In 1975, Iran offered to finance construction of a railway system to link Afghanistan with Iran's transportation network and ports as well as providing other transportation branches within the country; the project, scheduled for completion in 1983, would have cost $\$ 3$ billion. Offers to assist economic development in Afghanistan were made, but not executed as negative Soviet influence 1ncreased. The project was delayed for three years and scheduled to begin in 1978. Only three months before a communist coup toppled the Daoud regime, Business Week stated that the Kabul regime received, from a French company, a proposal for a railroad whose near-billion-dollar cost would be borne by the Shah's government and which would have integrated Afghanistan's mineral development with Iran's industrial development program -a prospect which would not have pleased the Soviets.

As a result of requests from the Afghan Ministries of Planning and Mines and Industries, a survey for the extension of the gas pipeline from the northern provinces to Kabul was, however, included in proposed projects of the World Bank and the Asian Development Bank. The Soviets resented the idea of involving western sources in the projects of northern Afghanistan, particularly in the hydrocarbon and minerals industry. According to members of President Daoud's entourage on his last fateful visit to Moscow, Brezhnev explicitly criticized the evergrowing involvement of western experts from the United 
Nations, World Bank, and other organizations involved in projects with Afghanistan - espectally their profects which dealt with the northern provinces bordering the Soviet Union. Brezhnev accused these experts of being agents of western intelligence and concluded that the continuation of this "situation" was against Soviet-Afghan "friendly relations."

President Daoud, increasingly fed up with the aggressive conduct of the Soviet authorities towards his government, and particularily the Soviet embassy's support for the communist parties inside Afghanistan, had become extremely agitated. He told his Soviet counterparts at the meeting that Afghanistan was a free country and did not need the advice of "other" countries in handling its domestic and forelgn policy. President Daoud then rose and began to walk out of the conference room. Brezhnev jumped up from his chalr after Daoud to speak with him and asked him to a private meeting. President Daoud responded that "it won't be necessary now." Because of this meeting, the communist coup which had already been planned by the Soviets for later in the year was moved up to Apri1, 1978.

These events were presaged by a meeting in Kabul between the acting Minister of Planning, Mohammad Khan Jalalar, and Pozanov, the then Soviet Ambassador to Kabul. The issue of the Afghan proposed oil reflnery was raised. The Ambassador reluctantly answered that a mission from the Gas and Petroleum Authority of 
the Soviet Union, along with a team of geologists was on its way to Kabul to review the possibility of oil development including the refinery. The Ambassador added that the heads of the Economic Cooperation and Trade Section of the embassy, Mr. Chebarov and Mr. Deedokh, would have further meetings with members of the Afghan Ministry of Planning to discuss the details.

Early in Apr1l of 1978, Chebarov and Deedokh arrived for the meeting but were in a jovial mood, looking back it seems as if they were in high anticlpation of the invasion. They did not want to enter into serious business talks. The Soviets attitude outraged the Afghans who had no idea that less than one month from then, the Soviets would control the entire country. The 200 geologists did arrive after the communist coup. Their supposed purpose was to initiate construction of three oil fields and a 500,000 ton refinery. The program was halted for "unknown" reasons, although the acting Minister of Planning, Mr. Jalalar, retained his high government position with the new communist government headed by President Taraki.

One of the first acts of the Taraki government in 1978 was to stress explo1tation of Afghan resources. Suspicion as to whom this explottation would favor was raised by Taraki's "close" association with the Soviets. Yet, the Soviets continued with their previous policy of submitting two reports on any energy 
research and exploration projects: a realistic assessment that was strictly for Soviet use, and a far more pessimistic report which was given to Afghan authorities.

In September of 1979, Amin, Taraki's Prime Minister, overthrew Taraki; a month later, the Amin government announced Taraki was dead.

An interesting event occured on December 17, 1979 when a Soviet news service, monitored and reported by the BBC, issued a furious attack on the French news agency. Agence France-Presse. It complained bitterly that "cases of the French news agency circulating anti-Soviet fabrications have become more frequent of late," and in particular fulminated against a report that "the Soviet Union has evidence of major oll reserves in Afghanistan but is keeping them secret from the Kabul authorities."

On December 27, 1979, ten days after the BBC interview, the Soviet Union invaded Afghanistan. President Amin was executed in his presidential palace and a new government was installed under Babrak Karmal. Western milltary analysts calculated that only 1020,000 of the 100-120,000 Soviet troops that were stationed in Afghanistan were needed for actual military operations, and that the rest were used in routine duties, building projects, and mineral mining. In addition, throughout the occupation, the 
Soviets charged Afghanistan for direct costs of the war. The Soviets were importing over 500,000 tons of o11 for the war effort. In 1980, a pipeline was built by the Soviets from the U.S.S.R. to supply petroleum needs of their military operations. There are two pipelines which bring this refined oil from the Soviet Union into Afghanistan. These pipelines were then paid for by the huge increases to the Afghan foreign debt but they delivered oil directly to Soviet military bases inside Afghanistan. Afghanistan literally fueled its own destruction. The foreign debt to Russia also financed the building of the Salang Highway which was the route of the Soviet invasion and retreat. The increasing Afghan forelgn debt was also used to finance the building of the airbases, housing, the "special" needs of Soviet advisors, heavy mining and drilling machinery, and a rail system to link the two countries.

With the onset of military aggression by the Soviets, Afghanistan's self determination toward 1t's own resourses was even more eroded. The devastating effects of forced decisions continued to thwart Afghanistan's economic possibilities as a result of direct Soviet interference. The events during this decade are chilling even without reciting the human dimension. 
In June 1987, Mining Journal stated that there were over 170 Soviet-aided projects that were either under construction or in production in Afghanistan. The few lines of information on Afghan minerals available for the Minerals Yearbook clearly is not consistent with this.

A statement by an Afghan spokesman at a news conference held in Kabul 16 October 1986:

"Afghanistan is a land full of mineral resources. Precious stones of our country enfoy an enormous reputation all over the world. During the past 10 years, other useful deposits have been discovered by Afghan geologists with the technical assistance of the Soviet Union, including 011 and gas fields and coal, copper, iron, barite, salt, gatch, and magnesium deposits, etc. With the discovery of the above-mentioned deposits, and other deposits, we can say that today a reliable base of mineral raw materials exists for the development of the main aspects of the country's economy and provides great possibilities for improving our people's lives. Most of the deposits are prepared for industrial extraction. Today in our country, natural gas, coal and raw materfals are extracted for cement production and for the chemical and construction industries." 
All utilization and extraction plans for Afghan energy and mineral resources were designed to meet Soviet and not Afghan priorities. Because of this, the Afghan people were denied the use of thelr own resources and forced to rely on imported energy sources or the utilitization of use of limited subsistence fuel (fuelwood, animal dung, etc.). This continued manipulation of Afghanistan's resources coupled with the continued effects of the war has been devastating to the people and to the countryside. 


\section{NATURAL RESOURCES: A Survey of POSsibilities}

The availability of a rich resource base of minerals and energy sources in Afghanistan has now been acknowledged. The resource potential of Afghanistan is very promsing and if properly utilized could contribute to rapid development and economic growth. The following is an overview of those resources and some of the existing facilities for their use:

NATURAL GAS:

It has been over a quarter of a century since huge reserves of natural gas were discovered in northern Afghanistan. Several geological surveys reveal that natural gas may exist in the south, and southwest, as well as the north of Afghanistan. Extensive gas exploration and exportation by the Soviets has concentrated naturally only in the northern provinces of Afghanstan which border on the Soviet Union. The quantity of natural gas which has thus far been discovered would be sufficient for Afghanistan's use. 
The natural gas reserves in the north are estimated at 100150 billion cubic meters. According to some Afghan geologists who have worked with Soviet experts, these numbers could be higher since the meters are located on the Soviet side of the border and Afghans are not permitted access to the area. When the Soviet proposal was put forth, Dr. Sharifi, a geologist who was director of AFGAS, argued against meters being installed on the Soviet side of the border. He proposed, instead, the installation of Swiss meters on the Afghan side of the border. In June of 1979, he was arrested and has not been heard from since. A true figure on reserves is currently unavallable since these were highly classifled by the Soviets.

From 1967 to 1979, the Soviets claim to have imported 30,4 billion cubic meters of gas, and from 1979 to 19882.3 billion cubic meters per year. The offictal figure from 1979 to 1988 is 4.0 billion cublc meters per year. The Soviets also claim that there is 160-200 billion cubic meters of gas remaining in Afghanistan. The Afghan estimate more than doubles that figure, Their estimates forecast that 320-400 billion cubic meters of gas remain. However, in The Russian Rope: Soviet Economic Motives and the Subversion of Afghanistan, Dr. Abdul Tawab Assifi, former Minister of Mines and Industries for Afghanistan (1975-1978), estimates that as of 1977 reserves were in excess of 500 billion cubic meters. 
In 1968, the Soviets began exporting the natural gas from Afghanistan at an outrageously low price of $\$ 16.20$ per 1,000 cubic meters ( $\$ 0.458$ per 1,000 cubic feet) in exchange for military hardware and ammunition which they used to pave their way to occupation in 1979. Afghanistan was never paid more than $20 \%$ of the going world market price for natural gas, while the Soviet Union paid three times as much for Iranian natural gas. The price was adjusted in the seventies by $30 \%$ at the urging of China to $\$ 5.6$ for one cubic meter of gas ( $\$ 0.59$ per 1,000 cubic feet). In 1972, the price was $\$ 6.10$, in $1973, \$ 6.60$, in 1974, $\$ 11.20$, in 1975-76, the price for natural gas was $\$ 16.20$. Export earnings from natural gas increased greatly in 1975 from $\$ 26.29$ million in 1974 to $\$ 46.80$ million due to a doubling of the soviet price pald for the commodity. (World price is currently $\$ 128.00$ per thousand cubic meter of gas.) In the new contract of 1980 between Afghanistan and the Soviet Union, $\$ 83.37$ was the price paid for 1,000 cublc meters which was one-third of the international price. Almost all of the 2 to 2.5 billion cubic meters of gas per annum were sent by pipeline to the Soviet Union. This $60 \mathrm{mile}$ long pipeline was completed in 1967 and opened in 1968. Only 5-10\% of the extracted gas is used in the $36,000 \mathrm{kw}$ thermal power plant and 100,000 ton per year fertilizer plant in Mazar Sherif. 
By these agreements, the gas is bought by Russia at 25 웅 to $50 \%$ below the correct international price. Thus Afghan gas is even cheaper for the Soviets than gas produced in the USSR. The Afghans do not recelve any monies for this resource. The money is kept by the Soviets to "help pay the interest on Afghanistan's debt and war costs."

Since the first exploration of natural gas, probably Afghanistan's most important mineral commodity, its use has been dictated by the Soviets. In 1955, Moscow gave a \$100 million dollar loan at 28 interest to develop Afghanistan's natural gas industry. By 1960, Afghanistan's debt to Russia had reached hundreds of millions of dollars. By the late 1970's, the debt was more than one billion dollars. In 1988, the figure was closer to ten billion. This money could never really be repaid by Afghanistan due to debilitating agreements signed with the Soviets. Afghanistan had agreed to give the Soviets up to $\$ 200$ million dollars per year, and still this does not cancel the debt which grows larger every year.

According to Minerals Yearbook 1978, an agreement was signed in February 1975 for a total of 2.8 billion cubic meters to be exported to the Soviet union. The remalnder of the 3 bilition cubic meters produced that year was used in the domestic power 
production and to fuel the Mazar-i-Sharif fertilizer plant. The combined reserves of Afghanistan's five principal gas deposits, all situated in the northern part of the country just south of the Soviet border, were estimated at 100 billion cubic meters.

In 1975, production was concentrated in the Khwaja-Gogirdak Field, while drilling continued at the Yatim Tag, Khwaja-Borhan, Juma, and Jarqduq Flelds. The Soviet Union also assisted in the construction of a pipeline extension completed in 1975. The new surface pipeline, which had an annual capacity of more than 4 billion cubic meters of gas, spanned the Amu Darya River to link the Khwaja Gogirdak wells with the Turkmenistan area of the Soviet Union. The Soviet Union further contributed to the construction of two gas treatment plants, one at Khwaja Gogirdak, wich was completed in 1975, and one at Jarqduq Field in Jowzjan Province, which was to be opened in 1976. Mining Annual Review 1987 also reported the the northern region around Shiberghan and Sar-i-pol is rich in natural gas, which is now being piped to the Soviet Union; the target was to supply 57.7 billion cubic meters of gas to the U.S.S.R. Gas production in 1983-1984 was 2.85 billion cubic meters of which 2.28 billion cubic meters was exported to the Soviet Union. 
Natural gas is delivered to the power plant by a $325 \mathrm{~mm}$ pipeline some $88 \mathrm{~km}$ long. Exports to the Soviet Union are piped in an $820 \mathrm{~mm}$ line linking the Shiberghan fields in the north to a measuring station at Kelift in the U.S.S.R. Plans were to add 1,000 billion cubic meters of natural gas, two million tons of coal and 500,000 tons of copper metal to exploitable reserves. Priority has been given to exploitation of the Jarqaduq and Khwaja Gogerdak natural gas flelds at Shiberghan, from which 2,700 million cubic meters of gas is being tapped, according to Soviet sources. Also according to Tass, the official soviet news agency, gas output was to be stepped up to 4.1 billion cubic meters.

Raw liquid gas is used in a few bulldings in Kabul. Some banks and hotels use this for central heating. According to Resistance sources, as of September 1989 since the Soviet withdrawal, gas has not been shipped on a regular basis to the Soviet Union. Most wells are still intact and in the hands of the government. In January and February of 1989, 38 wells were plugged by Soviet forces prior to the withdrawal.

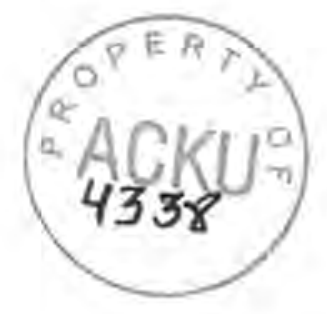




\section{PETROLEUM RESOURCES:}

Thus far, oil exploration activities have taken place only in the Karakum basin, and only 10\% of the oil has been drilled; but Afghan petroleum engineers feel the largest strike will come in the Kundar-Urgun basin bordering Pakistan.

Five major sedimentary basins with hydrocarbon exploration interest occur in Afghanistan:

1. Karakum Basin in northwest Afghanistan

2. Afghan-Tajik Basin to the northeast.

3. Tirpul Basin to the west of Herat.

4. The Helmand Basin

5. The Kundar-Urgun Basin in the South.

In 1975 and 1976, the Afghan engineers discovered additional oil reserves equal to those in Angot in Aq Darya and Qashqari. The Qashqari reserves hold better quality oil in three layers with reserves at 12 million tons. Bazar Kami, Biland Ghor, and Ali Gul also had strikes increasing the possibility of finding 
additional major reserves. Oll production in the north rose steadily by approximately 20 percent a year throughout the 1970 's. The Soviets claimed that there was 14 miliion tons of crude oil in Afghanistan. The Afghans in their explorations said there were 60-100 million tons of proved crude reserve. The potential is not known and this figure comes from the Karakum basin only. The production of 500,000 tons per year of crude oil is therefore feasible and could be used to make the country energy self sufficient.

At the same time, negotiations were ongoing with western companies to explore for oil in the south, southwest, and the west of Afghanistan. British Tricentral contracted for Farah, and American Cities Services was interested in Dasht-1-Margoht and Registan areas. According to Minerals Yearbook - 1978, in 1974, a contract was signed with the French company, Compagnie Francaise des Petroles (CFP), to explore hydrocarbon reserves in the Kundar area of Urgun.' They were awarded 20,000 square kilometer exploration area in the Katawaz Basin in the southeast which constituted a geological extension of CFP's exploration tract in northern Pakistan. As part of the agreement, CFP contracted to train Afghan personnel in oll and gas technology in France to make maximum use of the local Afghan labor force, and to carry out the future production and transfer of gas and/or oil commodilties within the framework of joint companies. CFP was 
required to spend 17 million dollars in a three year time span. However, CFP did not complete its contract obligations, as the Soviets were very determined to maintain control of Afghanistan's hydrocarbon industry.

Afghanistan had no crude ofl output in 1975 and a flow of only about 150 barrels per day of condensate from the Sar-i-pal Field in southern Jowzjan Province. The Soviet Union provided Afghanistan with nearly all its petroleum product requirements, which were estimated at about two million barrels. The search for indigenous petroleum resources continued in 1975, and exploratory drilling indicated a second oil-bearing area in the Aq Darya District of Jowzjan Province. Reserves of 2.5 million tons of recoverable oil had previously been discovered at Angut, approximately $7 \mathrm{k}$ llometers from Aq Darya. Details pertaining to the oil refinery planned for Jowzjan Province were also announced in 1975 .

Afghanistan's first oll refinery was to be located 65 kilometers from the Angut and Aq Darya Fields and to be built with Soviet technical assistance. The refinery was scheduled to process approximately 1,100,000 barrels of crude oil and produce about 728,000 barrels of fuel 011, 371,000 barrels of diesel oil, 133,000 barrels of tar, 91,000 barrels of gasoline, and 42,000 barrels of kerosene per year. In 1980, the Soviets constructed 
a pipeline from the USSR to supply the petroleum needs of their military operations. However, prior to the February withdrawal in 1989, the pipeline was attacked by the mujahideen with wide spread destruction. Following the withdrawal, a good portion of the remaining pipeline was taken back by the Soviets when leaving the country. In the future, it would be possible to construct an extension of that pipeline for distribution and export purposes. With technical help, Afghanistan could finally begin exporting crude oil within three to four years. Reports reaching Pakistan as of September 1989 indicate that all oil wells are now sealed.

COAL:

The World Bank indicated at one time that vast coal deposits in Afghanistan together with many other resources should spur major development according to Dr. Shroder in Afghanistan Resources and Soviet Policy. In 1975, the Minerals Yearbook cited 11 coal deposits with total reserves of 300-500 milition tons; the total output that year was 160,000 tons. Coal mines occur across the mountain range between the Pamirs to the northern slopes of Herat-Badghis, with Kabul being the main market. Business Week, in 1980, reported the reserves to be 400 million tons, and cited them as of new importance to the USSR because of difficulties with Polish supplies of coal. In 1987 , 
Mining Journal's annual review cited plans to add 2 million tons of coal to exploitable reserves, estimated coal deposits of 100 million tons of high-grade proved reserves and $400 \mathrm{Mt}$ in the probable category, and said production is to be expanded to 300,000 tons from the 1980-81 production figures of 118,000 tons. The Economist's World Energy reported that Afghanistan ranked 46 th in coal production in 1981 with 125,000 tons.

The coal mined in Darl Soof is good for steel production and is considered the best quality. Coal has been extracted from Kar Kar, Dodkash, and Dar1 Soof in the northern areas of Afghanistan. Dari Soof has the largest coal deposits (60 million tons) and Ashpunta near Doshi in Baglan province is a branch of Kar Kar, the second largest coal deposit which contains 15 million tons. Prior to the communist takeover, the President of Kar Kar was also the General Director in Ashpunta. The Afghan Resistance has wrested control away from the communists at two of the mines Ishpatul in Bamiyan and Dari Soof in Samargand Province. In early 1986, agreements were signed between the Kabul regime and Czechslovakia for coal mine projects in the Herat and Sabzak areas. Czechslovakia supplied mining equipment for exploiting hard coal mines in the north, but the Sabza mine in Herat has no electricity. Strojexport planned on delivering equipment for reconstruction of northern mines which would help raise production to 180,000 tons per year. 
Coal in Afghanistan is used in cement plants, textile mills, cotton mills, a sugar mill, the government bakery in Kabul, and for domestic use. Development of coal mining and production was given top priortty by the communist Kabul regime at the urging of the Soviets. Extensive development of the coal deposits and its extraction was in the best interest of the Soviet plan to keep the Afghan population dependent on this fuel source rather than the natural gas which was flowing from Afghanistan into the Soviet Union. Several factories of compressed fragments briquets were to be installed for domestic use from 1979 onward by the Bulgarians. The production target from 1991 onward was set at 370,000 tons per annum. Coal has many uses especially for electricity but the electrical supply will not be enough for the returning refugee propulation.

\section{ELECTRIC GENERATION:}

Total hydroelectric potential for Afghanistan is estimated to be 2,500 MW, not including the massive canyons of Badakshan through which the Amu Darya flows and which greatly increase the hydroelectric potential of the region. However, the total electrical output capacity of Afghanistan is estimated at over $400 \mathrm{MW}$. Hydropower accounts for $256 \mathrm{MW}$, thermal power is 48 to $60 \mathrm{MW}$ and the remainder is diesel generated power. Afghanistan 
had built ten hydroelectric plants with more than half on the Kabul River system, two on the Helmand, and two in the north. In 1981, The Economist publication, The World in Figures, ranked Afghanistan 105th in electrical producers in the world with 1,018 KWH. Only $6 \%$ of the population has access to electricity and almost all of the nation's total electricity is used in the major cities for illumination, cooking and heating purposes.

Due to the escalation of the war, and the Afghan Resistances' successful attacks against and eventual control of the power stations and power lines, only a small percentage of the installed capacity is able to be used. Power shortages in Kabul during the winters of 1988 and 1989 were severe. Two milion reside in Kabul and even when it was less than one million prior to the war, electrical shortages were notable. To offset this shortage, the Kabul regime has purchased hundreds of diesel generators to cover some of their electrical supply needs. The thermal power station is the main alternative to hydropower plants. Hydropower plants and power lines can be rehabilitated and should be a primary focus of reconstruction effort.

The World Bank was asked to finance turbines in Pol Charki as peak demand was exceeding capacity. The project called from 55-60 MG in Kabul area for 1980. The World Bank did supply \$1314 million dollars for the first thermal plant in Kabul which was 
in operation prior to April, 1978, and a Swiss firm supervised the construction. After the communist coup, Russia built a thermal power plant in Kabul with the same capacity. Another thermal power plant was established by Communists in Kabul with the same capac1ty of 50-60 MG.

The Soviets have bullt two electical lines from the Soviet Union. One $1 \mathrm{~s}$ a $220 \mathrm{KV}$ whtch extends to Mazar Sherif and has been completed to Balkh. The oxus rlver port of Hairantan is now connected to the soviet power grid by a $222 \mathrm{KW}$ transmission line according to the June 1987 issue of Mining Annual Review. The other completed power line is of $110 \mathrm{kV}$ which extends to Konduz. The Soviet Union sold electricity to Afghans during the last three years and in $1986 / 87$ sold 37 million KW hours.

A project to connect Kabul with Mazar Sherif was developed during Daoud's time and continued under the Soviets. Large amounts were spent on transmission. The Soviet Union needed electricity for copper mining. Prior to the coup, 100 MG was needed for utilization of copper according to Afghan sources. An alternative site was located in the Kunar area. Government studies through a Swiss firm identified several alternatives: 500-600 MGW and 300 MGW in 1978. President Daoud wanted to use Kunar electricity for copper but the Soviet Union wanted to extend to Logar. The Afghan government received two study proposals in 1978, but the Five-Year Plan (1979-1984) put forth 
by the communists laid emphasis on developing hydroelectric stations.

RENEWABLES:

At the turn of the century, most mountains in the 27 provinces were heavily forested. Today only 5 provinces, Paktia, Paktikia, Kunar, Nooristan, and Badghis have remaining forests. Afghanistan had a total amount of 1.9 million hectares of forest ( 3 \% of total land surface) before the escalation of the war in Afghanistan. The Soviets over the past eleven years as part of their scorched earth policy, made forests and their related facilities and their infrastructures targets of their massive aerial bombardments. The traditional source of domestic energy for cooking and heating in Afghanistan is fuelwood. The extensive and ever increasing use of fuelwood for cooking and heating along with the war's devastation have left many areas burned and ecologically devastated.

As the population of cities and towns increases, so does the need for wood for fuel and construction. Some alternative energy sources were introduced over the years such as briqueted coal, oil, and electricity, but in the cities they were in limited supply and in outlying areas, nonexistent. In regions where shortages of wood was severe, the population has resorted to extracting grasses and shrubs along with their roots from the 
earth. Deforestation caused by demand for fuelwood ( 80 o of domestic energy supply) has resulted in the reduction of soil degeneration which will severely reduce agriculture output.

Prior to the communist coup in 1978, the previous governments had designated forests as national parks. With the communist takeover and the Soviet invasion, the central government lost control of these parks and trees were irresponsibly cut down and elther smuggled to Pakistan or carried to the main cities of Afghanistan.

With the end of the war in sight, and the eventual return of 5 million people, there will be an increased need for construction timber and expecially for fuelwood which will put an additional strain on Afghanistan's forestry resources. The majority of the five million returning refugees are from those areas where the last forest sites are located. If prompt action and clear and concise planning are not $1 \mathrm{mplemented,} \mathrm{further}$ devastation will result.

\section{URANIUM:}

According to U.S. diplomats in the early 1960's, Soviet geological survey teams along with a few thousand military advisors began to prospect for uranium not far from Kabul. 
Various reports have for some time stated that there are significant deposits of uranium in Afghanistan, and that the Soviets are importing it. The Minerals Yearbook published by the U.S. Department of the Interior for 1978-9, which relies in part on information received through the United Nations, refers to a large deposit of uranium in southwest Afghanistan.

Also in 1980, the U.N. possessed a report originally prepared by the Soviets themselves that referred to an important high-grade uranium deposit in the southwest. This overall report led to a favorable World Bank assessment of the country. No less an industry authority than McGraw-Hill's NuclearFuel gives credence to this story, and the vehemence and nature of Soviet denials leads to belief in its veracity. They stated emphatically in 1984, for example, in reply to a Nuclearfuel article, that..."there is no uranium in Afghanistan, if there was we would know about $1 t$, and that we are not mining it."

Also in 1984, NuclearFuel stated that "rumors that the Soviet Union faces uranium shortfalls may be at least partially substantiated by a recent report that the Soviets are mining uranium in Afghanistan and shipping it back to their country," Their information came in part from an Afghan defector reported to have been with the Soviet geological team at the mining project in the Kwaja Rawash mountains as the chief engineer in 
the geological survey of Afghanistan's Ministry of Mining and Industry. As early as 1982, the Afghan Resistance had recognized the value of these geologists and the senior Soviet in the party. E.R. Okhrimyuk was captured and killed by Gulbuddin's Hezbi Islami party in 1982 .

In June 1987, the Annual Review of the 1nternationa1 publication based in London, Mining Journal stated that Soviet geologists have mapped out deposits of uranium, and that uranium from the Khwaja Mountains east of Kabul is sent to the Soviet Union. Uranium is also reported in Kunar, Nimruz, and Logar provinces. Though the Soviets claimed they were mining copper rather than uranium, a 1988 joint report by OECD Nuclear Energy Agency and IAEA entitled Uranium Resources, Production and Demand, "uranium does occur in copper deposits, and is being recoverd as a by-product of copper leaching in India which has significant resources.

Independent sources in Islamabad confirmed for NuclearFuel the presence of uranium in the Kwaja Rawash area as well as other parts of Afghanistan. The Khanneshin volcanic complex on the lower Helmand is also referred to as being rich in uranium and rare earths. 


\section{COPPER:}

The World Bank Report of 1978 indicated that the huge copper deposits from Alnak, south of Kabul in Logar province, could capture two percent of the world market according to Dr. Shroder in Afghan Resources and Soviet Pollcy. The 1984 Minerals Yearbook stated that the Ainak copper deposit was to come onstream in 1985, and that the profect was expected to produce 150,000 tons per year of copper, most of which would probably go to the U.S.S.R. In 1975, total copper reserves in the Kabul region were estimated at 3.5 million tons from $0.7 \%$ to $1.5 \%$ high quality grade, which makes it richer than the Sierra Colorado deposit, which was then about to be developed in Panama. At Ainak itself, reserves were estimated at between 1.5 and 2 million tons grading 1.3\% copper in 1975, with other sites in the north being explored. Mineral's Yearbook - 1978 states "exploitation of the deposits at Alnak together with the construction of a copper smelter was planned for 1977. Surveylng also took place at the Darband and Jowhar copper deposits with 12 million tons estimated making it one of the largest single deposits in the world.

McGraw-Hill's NuclearFuel mentioned in an article on Afghanistan that there were reports of copper mining by the Soviets at the Ainak mines in Logar and establisment of a copper smelter near Kabul 11 nked by a $17-m 11 e$ road to the mines. A 
Soviet document captured by the Afghan resistance and quoted in Afghanistan: The Great Game Revisted states "in size, richness and copper content the deposits appear to be the largest in the world." Ainak actually is capable of producing twice as much as the Soviets spoke of in Afghanistan Resources and Soviet Policy 11.5 million tons of copper in comparison to the front-ranked Soviet Dzhekkazgan deposits which are only one-fourth to onethird as large as those at Ainak, and the Bingham copper deposit, the largest open pit mine in the world which produced only 9 militon tons of copper in its lifetime.

IRON :

The third largest iron deposit in the world, according to French estimates, is located at Hajlgak, 60 miles northwest of Kabul in the Hindu Kush mountains. Mentioned as a significant addition to Afghanistan's mineral profile in the 1975 Mineral's Yearbook, reserves there were given as 2 billion tons with an iron content of over 60\%. Preliminary surveys by the Soviets showed the Hajigak ore to the largely high-grade, directly shippable pyrite-magnetite with an unusually high grade of $67 \%$ iron. Measured reserves are about 111 million tons and estimates based on reasonable geologic inference are more than 2 billion tons. Geologic reports showed 5 deposits, Geologic reports showed 5 deposits, 52 occurances, and 12 showings of iron in 
Afghanistan. However, the lack of infrastructure made the cost of developing these reserves prohibitive for pre-communist Afghanistan.

In 1951 the German and French firms prepared a study on a possible mining profect for iron ore for export to Pakistan of approximately 150,000 tons. Currently, Pakistan imports the iron ore necessary for 1 ts Russian built steel mill in Karachi from Australia. Once peace is established in Afghanistan, ore shipped from Hajigak could be used in the Pakistan mill if both nations should agree to this proposal. As Business Week points out, "the Soviet Union's remaining reserves of iron-ore amount to more than 10 billion tons of ore with an iron content of less than $55 \%$. As the average richness of all Russian reserves is only $38 \%$, most Soviet Union iron requires costly upgrading -- a process that the Hajigak reserves would not need. Moscow had seen development of the Hajigak iron ore for steel mills in Tashkent as a way to amortize Soviet capital expenditures on Afghan gas and oil development.

\section{Chromium:}

The 1975 Minerals Yearbook referred to "potentially important deposits" of chromium. Business Week reported in 1980 that Afghanistan has high-grade chromium ore in Logar Valley and near Herat -- and had previously reported that Moscow's own chrome ore quality is falling rapldiy. The Logar deposit near 
Kabul is said to have about 180,000 tons of 42 percent ore, although unpublished work by German geologists are cited as Indicating 2 and a half times these tonnages. Additonal Afghan surveys estimate 300,000 tons. Business Week cited a 500,000 ton Afghan resource potential. According to Business Week interest from the Soviet Union in the high-grade chrome ore comes from the fact that Moscow's own chrome ore quality is falling rapidly.

It should also be kept in mind that the Soviet Union and South Africa alone conduct most of the world trade in chrome ore, manganese ore, platinum group metals, asbestos and gold; that the United states has indeed been forced to buy chromium, necessary for defense purposes from the Soviet Union.

Dr. John Shroder left us with an interesting thought.." the Logar chrome deposit may be important to the Soviets--both as a resource for themselves, and for potential denial to a dependent West."

Miscellaneous:

Barite: In 1975, deposits were cited of 200,000 tons in the Farinjal area of Ghorband and Sanglon area of Herat, with 5,200 tons produced. Sanglon has depostts of 1.5 million tons. The 1987 Mining Journal annual review referred to deposits in Bamyan province. 
Talc: In eastern Afghanistan, Talc deposits are one of the biggest in the entire world - 700,000 tons. 3,000 tons were produced in 1974, 6,300 tons in 1975 .

Marble: 10,000 tons were produced in 1975, most of which was used domestically.

Salt: Salt production began in 1959, and reached a level of 60,000 tons in 1975, two-thirds was rock salt from open-cast mines near Tallequan in Takhar Province and the rest from brine lakes near Herat, Andkhol and Kandahar. In Kalfgan alone, deposits contain 130 million tons of salt which is sufficient for 15 centuries of domestic use.

Beryl: In 1975, Minerals Handbook referred to "potentially important deposits."

Precious Stones: In 1975, reserves containing lapis lazuli were estimated at 1,500 tons, with 8 tons of jewelry-grade produced that year from Badakhshan. Rubies are found east of Kabul in the Jegdalek area. Emeralds are found in Nooristan and Panjshir districts. Kunzite is found in the Kulam Valley of Nooristan and Nangarhar province. Aragonite-onyx is found in the southwest of Lashkaragh. 
Gold and Silver: Both gold and silver have been mined since ancient times in Afghanistan. According to prevailing studies some 30 tons of gold have been determined.

Beryllium: The 1987 issue of Mining Journal cites deposits in the Kunar Valley.

Other: Asbestos, mica, sulphur, celestite, flourite, bauxite, 11thium, barium, cesium, tantalum, nioblum, magnesite and muscovite, fluorspar, zinc, bauxite, and lithium are also available but figures are not currently available.

Mineral Dependent Production:

\section{Cement:}

The first Afghan cement production in 1958 was made possible by huge supplies of limestone and coal. In 1966, production was 158,000 tons per year; in 1975, 140,000 tons were produced at two plants built by Czechoslovakia, with $40 \%$ shipped to the USSR and Iran. In 1977, elght quarries and two plants in operation at Pul-1-Khumeri and near Kandahar. Herat had plans for a 210,000 ton capacity plant and a second Kandahar plant with 840,000 tons. There were plans for expansion, to make cement as a principal export 1 tem and these plants would have provided an export surplus after domestic consumption was reached. 
Dr. Shroder states that in 1981, "a most peculiar trade protocol for cement was signed between Afghanistan and the Soviet Union: an agreement to exchange each other's cement production ton for ton. This odd arrangement can be understood when it is realized that soviet cement is of inferior quality and cannot be sold on world markets, whereas Afghan cement is manufactured according to internation standards and can be sold on world markets to the hard currency benefits of the soviets. In 1987, the Mining Journal's annual review cited 77,000 tons of production, with most being sent to the USSR.

Fertilizer: The fertilizer and powerplant complex at Mazeri-Sharif produces fertilizer estimated to be worth $\$ 10$ million annual1y. In $1975,45,000$ tons were distributed domestically to farmers throughout Afghanistan, and the plant's capacity was given as 105,000 tons, with another plant planned. In 1978, a joint Soviet-Afghan project for the construction of a second artificial fertilizer plant in the northern part of the country was being negotiated. In 1987, Mining Journal reported, most fertilizer produced was sent to the USSR. 


\section{THE FUTURE: REHABILITATION AND RECONSTRUCTION}

It would be naive to expect a war torn country with a poor industrial background and devasted manpower sector to change into a major exporting country overnight. But the time is right to move in that direction. Energy will be among the first 1 tems that must be provided to Afghans as part of their relief assistance. The already disastrous ecological situation will be further exacerbated with the return of the refugees and will result in further environmental problems as well as diminishing land productivity. These problems are well known to concerned organizations and several energy/fuel alternatives have been prescrtbed by the rellef organizations dedicated to providing assistance to Afghan refugees and the internal refugees. While Afghans will have to depend on a variety of fuels as they return to rebuild their country, 1t is crucial to lay the foundation for use and development of those energy sources, whlch have been abandoned in their country.

The extension of the gas pipeline, to southern Afghanistan must begin. Work on increasing installed capacity of gas powered thermal power stations should commence as soon as security returns to the country. Electric energy for the northwestern provinces of Afghanistan, Balkh, JowzJan, Faryab and portions of 
neighboring districts must be provided for. Limited potential exists for bullding hydropower plants in these provinces: additionally, their cost would be very great, Only the Amu Darya has enough water in this region to satisfy the need for hydropower in these provinces and perhaps other regions. Use of this border river with the USSR will require a joint investment of Afghanistan and the Soviet Union, which would seem to be unlikely for the immediate future.

The availability of a relatively rich resource base of minerals and fuels in Afghanistan has now been acknowledged. The potential of Afghanistan is very promising and if properly utilized could contribute to rapid development and economic growth. While Afghans will have to depend on a variety of fuels as they return to rebulld their country, it is crucial to lay the foundation for use and development of those energy sources, which have been abandoned in the country.

Soviet control of Afghanistan's mineral wealth would have a significant long-range impact upon the region of Southwest Asia economically in terms of energy supply and upon the relative positions of the U.S.S.R. and the free world, especially the United states. The Soviets have recognized these facts for a long time. This affected their decision to invade Afghanistan, and has been further evidenced by their continued actions, and is certain to play a part in their calculations as shown in the perpetual signing of numerous specific treaties even after their 
withdrawal had taken place. In 1987, the stated purpose of the "Joint Soviet-Afghan space flight was to research "underground mineral deposits, water resources as well as studying of river courses which also reveal mineral resources in the Democratic Republic of Afghanistan." The extent of the agreements still being signed between the two countrles demonstrates that the Soviets belleve there is still some value left to be extracted from Afghanistan. 


\section{Human Resources and Reconstruction Planning}

Human resources must be considered in order to correctly assess the energy dimensions and potential needs of a post war Afghanistan. The human factor is a fundamental resource that should be an integral part of a reconstruction plan. Even now, men and women are tolling in the yoke of oxen destroyed in the long years of war.

It is essential to fully assess the possible human contribution to a planned reconstruction now, before the hostilities cease and the refugees return to their homeland. An indepth and representative study utilizing current anthropological methods of the needs and lifeways of the Afghan people who are currently living in the refugee camps in Pakistan would contribute invaluable information for reconstruction plans and strategies.

Human resource reconstruction would include all aspects of resettlement. Methodologies to provide for food, water, health care, mine awareness, physical security, mine detection, and education and training must be developed now. Human resources have been ravaged by war: emigration and loss of life have taken an inestimable toll in all fields of endeavor. Education and training at all levels has been nearly non-existant during the 
span of the ten year war. Complicating this tragedy is the widespread destruction of the basic infrastructures needed for subsistence: roads, schools, hospitals, farmlands, irrigation systems, villages. Unfortunately, living conditions and health standards in Afghanistan were among the lowest in the world even before the war.

An assessment of 11 feways and subsistence pattern which would focus on existing skills and training, interest in technical training and skills development, communications links, information and technology transfer, and the expectations and hopes of the Afghan refugees will serve as an integral tool for decision making in the reconstruction process. Initiation of this study must be accorded top priority in order to prevent additional hardship and human suffering.

Experts predict that the relief and rehabilitation period in Afganistan may last for three years. The refugees in Pakistan and Iran as well as the internal refugees inside Afghanistan will want to return to their homes. The houses and infrastructures which were destroyed in the war will be rebuilt during this period. In the first phase, most of the efforts of foreign donors and the new Afghan administration will be concentrated in providing emergency aid to returning refugees as well as the rest of the population. The remalnder of the period will be allocated to reconstruction of the infrastructures. 
A substantial amount of forelgn ald is expected to be offered to Afghanistan during this period. A successful utilization of these resources would finance multipurpose projects such as the use and development of the abundant natural resources. It is estimated that $40-608$ of the reconstuction costs of Afghanistan should be in the energy sector.

After the third year, a sharp decline in foreign assistance is expected. A leading sector will be required to generate enough of a surplus to fill the gap of reduced foreign exchange flow into the country. The energy and mineral sector is the obvious answer to this need. Therefore, efforts must be made for the development of hydrocarbon resources throughout the initial three year period. The integrated development of this sector has the potential to meet the country's domestic needs and generate sufficient surplus for the long term development of the country.

The right choice of alternatives is crucial for a variety of reasons. The production of the existing sources of energy is less than the demand for $1 \mathrm{t}$ and this does not account for the addition demands of the flve million returning refugees. Alternative sources must be provided quickly and must be easy to use to encourage the refugees to use fuel other than wood from their forests. 
There is no doubt that Afghanistan contains rich resources of hydrocarbons and minerals. The hydrocarbon resources are very promising based on the limited exploration between 1975 and 1978 in only one of the five main basins. Enough oil was discovered, in addition to 1dentification of greater oil reserves, to provide a steady production increase of $20 \%$ per year throughout this short period of time.

Future development of Afghanistan obviously depends on a stable government that enjoys the support of the majority of Afghans. The Afghans have ably demonstrated their distaste for totalitarian and dictatorlal regimes. It is a logical assumption that they will install a more workable government that suits their culture and needs. A functionfing stable goverment supported by the people will ensure steady economic and resource development that will not only enhance their rebuilding efforts, but will also lend peace and stability in the region. Coupled with the high resource potential of the country, the future development of Afghanistan obviously depends on continued assistance from western nations without fostering dependence or economic bankruptcy as is so often the case in third world countries today. 


\section{CONCLUSIONS: FUTURE ENERGY SOURCES}

Afghanistan is unique among developing nations in that its abundant natural resources and perception in world opinion allows the possibility for innovative approaches to economic initiatives and sustainable development. Further studies in a variety of areas are required for a comprehensive approach for an effective reconstruction program. For instance, studies are needed to complete information regarding electricity generation. Cost effectiveness and energy alternatives must be contrasted, for example the feasibility of hydropower and coal generation should be considered from economic and environmental standpoints.

Introduction of natural gas as a source of domestic energy and the development of the oil 1ndustry would revolutionize the energy sector in Afghanistan. The extension of the gas pipeline to the major consumption centers and distribution networks requires a substantial amount of time and investment. Meanwhile, it will be practical to have a factory for concentrating gas into metal containers, similar to what exists in Iran and Pakistan. A private company, Afgas, was importing gas in similar containers from Pakistan for several years for domestic use in Kabul. A gas exploration program to meet the increasing needs must be initiated. 
A nationwide distribution system will be needed for supplying several rellef 1tems including fuel. Distribution of gas containers could be facilitated in this same channel. In later stages the evolution of a commercial national gas distribution network could evolve from within the initial relief distribution system. Natural gas tanks and stoves are inexpensive and readily available in Pakistan. Their use and repair is simple. Existence of relatively light weight tanks and stoves makes the use of natural gas on a community basis easy and could be used as an alternative fuel. Also, the use of natural gas will result in a substantlal savings in foreign exchange which has to be spent on other alternative energy sources. It will accustom the people to a cleaner and more efficient source of energy.

In the past, development of energy sectors, and consequently economic growth, has been hampered by the lack of all year roads, lack of raflways and the ability to transport minerals, goods and services. Development of these fundamental framework structures must be of the first priority. A French firm prepared two studies in 1978 on transportation and concluded that at that time, $\$ 300$ million needed to be spent on roads from the mines to railway lines, In Afghan Resources and Soviet Exploitation, Dr. Shroder points out that Daoud's development of Hajigak was to 
have become a major project to construct an infrastructure of roads, rallroads, and other transport facllities for mining, processing, and marketing. SOFRERAIL did the surveys and designs for an integrated rall network that was to extend from Herat to Kandahar to Kabul with a spur to Hajigak and connecting links to the Iranlan, Soviet, and Pakistani borders.

Construction of main artery roadways and the enhancement of the perimeter ring road should be of primary consideration. (See attached maps. Nearly all roads in the northern secotrs are reportedly unpaved.)

The U.N. estimates that 10,000 barrels of oil per day -3.6 million barrels per year or 1,400 tons per day - will be needed to run the country during reconstruction. They anticipate that 500,000 tons per year would be sufflcient for a 2-5 year program. Afghans would be able to exist with this amount of fuel at the beginning of reconstruction, but after five years the Afghans anticipate extra capac1ty would be needed for domestic use and increased economic activity. Currently one gallon of gas used by the mujahideen that is purchased from Pakistan is approximately $\$ 5.00$ per gallon (one gallon is 600-1,000 Afghanis and 1 Afghani is worth 100 Rupees.) 
Installation of a 500,000 to $1,000,000$ ton refinery of crude oil must be considered as soon as the security situation permits. Similarily, the exploration activities must be expanded to all potential major oil and gas zones from the very first days of returning to Afghanistan. Use of crude oll and condensate has to be promoted in the early stages of rehabilitation of the country. The traditional use of these materials exists in the thermal power plant of Kabul and in the central heating systems.

SOLAR ENERGY is one of the alternatives to be considered as an energy base as Afghanistan enjoys over 300 days per year of sunshine. In 1981, Solar energy was used in private homes in Afghanistan, but it was not very common in the market. Prior to the war, the U.S. Agency for International Development had projected that the cost of solar for one rural family would be $\$ 3,000$ per family. One area of interest is the use of solar power for irrigation pumps. The engineering faculty of the University of Kabul had reserved projects and prepared models to use for heating water. Solar cookers have been introduced successfully into the Afghan refugee camps and the Afghan women chosen to teach their usage found little resistance to this innovative design. 
PHOTOVOLTAICS would also serve both economic and sociological purposes in Afghanistan. It 1s economically feasible for remote area electrification profects as is shown in the DOE project currently underway in the Republic of the Marshall Islands.

BIOGAS The use of biogas is another potential project. This source also needs a considerable amount of investment at the household level for limited use but has the advantage of providing energy for remote areas. UNESCO has successfully introduced this technology is rural areas of Pakistan. The simple task of bolling water and cooking food from biogas has reduced infant mortality substantially in many remote areas.

COAL is found in vast quantities in Afghanistan. It could be encouraged as an alternative to partially replace fuelwood for cooking and household heating throughout the country. However, coal mines are located in northern Afghanistan. Lack of coal distribution networks will be one of the first obstacles to a vastly used alternative energy source. Also, its domestic use is more Ifmited compared to fuelwood and other alternative sources such as biogas and solar. Moreover, expanding the extraction of coal, to a level to meet the national demand, would require more investment, more labor force and improved management. To meet 
these demands, time will again be the factor which limits the effectiveness of coal as an alternative energy source. The air pollution factor must also be considered in using coal.

ELECTRICITY: Given the geographic locations and devastation as a result of the war situation, the installed electric capacity serves only a small percentage of the population. The expansion of electricity generation and distribution networks requires considerable investment over a period of time. However, in the long run the increased electrical supply in key areas will facilitate the development of industries and manufacturing sector. A national grid system must be part of the initial development plan. Currently, there 1 s a turbine in Kandahar and a place nearby 1 s also avallable for a 51 MGW capacity generator. The first construction phase should be from Kandahar to Kabul. The second phase of construction should be from Ghazni to Qalat. This electrical generation will be of tremendous help to the agricultural sector for pump irrigation.

KEROSENE is a fuel that may have vast uses as an alternative source of energy for the emergency relief period. This commodity is easy to use, kerosene stoves and lanterns could be readily found and priced inexpensively and the people of Afghanistan are well acquainted with 1 ts use. But, despite all practicality and simplicity of use, until the petroleum industry can produce it, 
kerosene must be imported. As this 1tem is consumed, it is exhausted and will have no long term stimulating effect on the improvement of domestic energy sources. 


\section{A Final Note}

The transformation of a poverty stricken and war torn Afghanistan into a vibrant and growth oriented economy is possible by careful planning and pragmat1c choices. Energy in the form of abundant natural resources provides Afghanistan with the fundamental tools to achieve economic growth and selfsufficiency. The opportunity exists to move from less efficient energy strategies to a more modern approach to economic development. Energy, technology, informed development strategies, and an appreclation of human resources can enable the Afghan people to rebuild their country. The choices made now must be based on an understanding of the human needs and potential of the Afghans themselves. The use by the Afghan people of their own sources of energy will be a matter of national pride and will be considered as the first fruit of independence. 


\section{APPENDICES}

\section{MAPS OF AFGHANISTAN}

1. Afghanistan and Bordering Countries

2. Provinces and Capitals

3. Transportation and Gas Fields

4. Kabul and Surrounding Provinces

5. Northeastern Afghanistan

6. Hydrocarbons and Non-metallic Minerals

7. Metallic Minerals

8. Mineral Resources in Afghanistan

9. Transportation Infrastructure

10. Development of Infrastructure on Afghan/Soviet Border 11. Soviet Contract 1968 


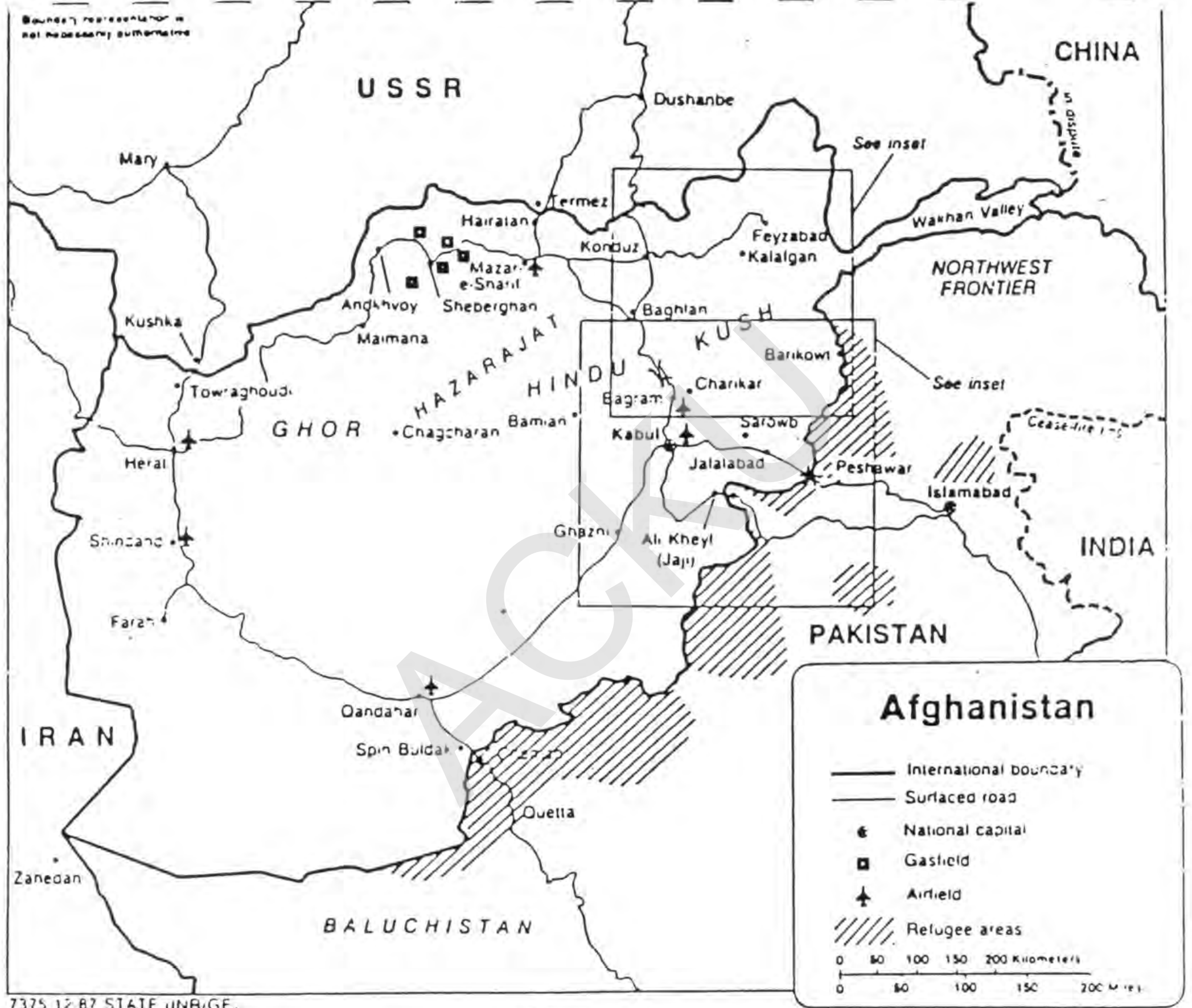

73751287 STRTE INAR,GE, 


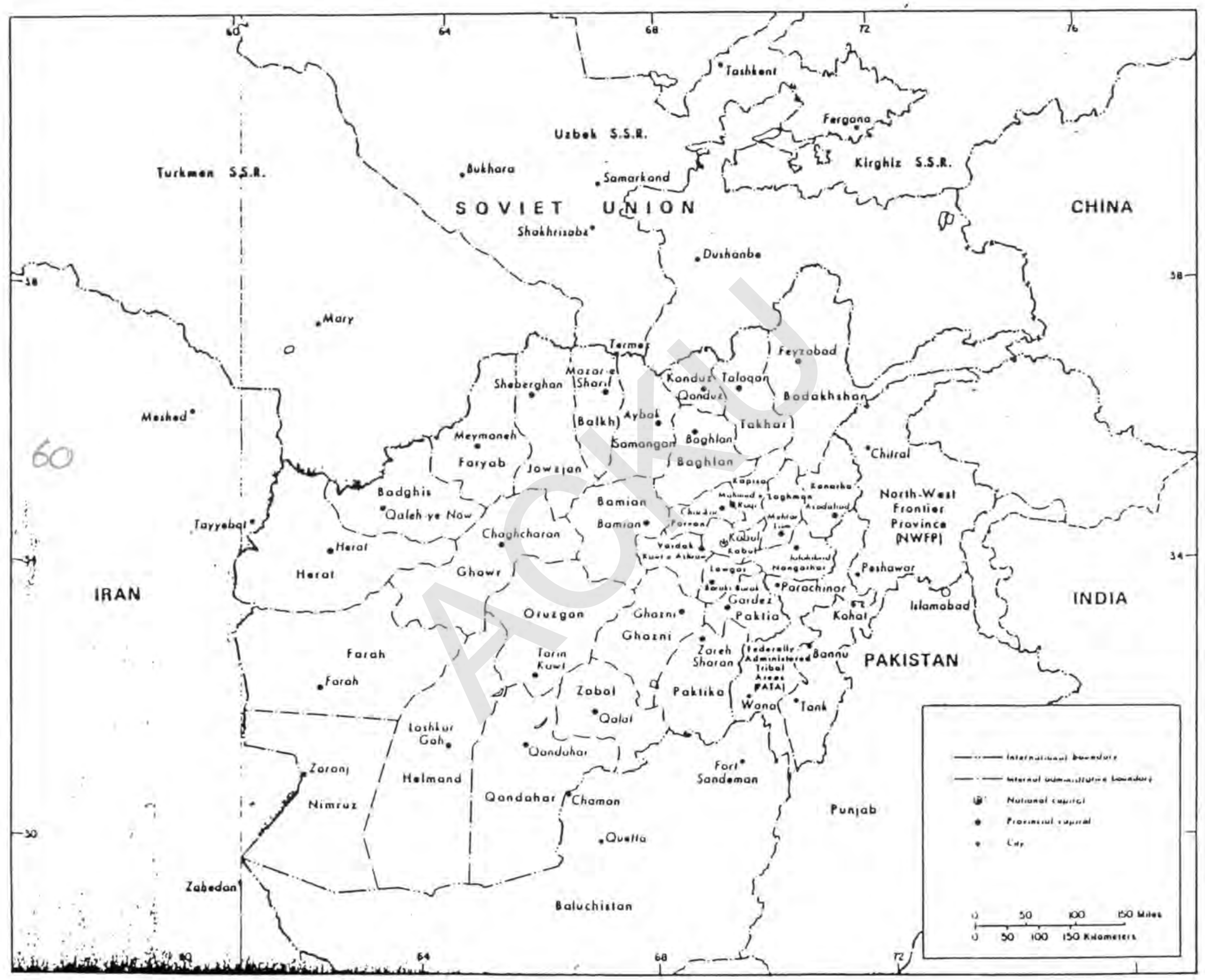

Figure I. Provinces and Cavitals. 1985 


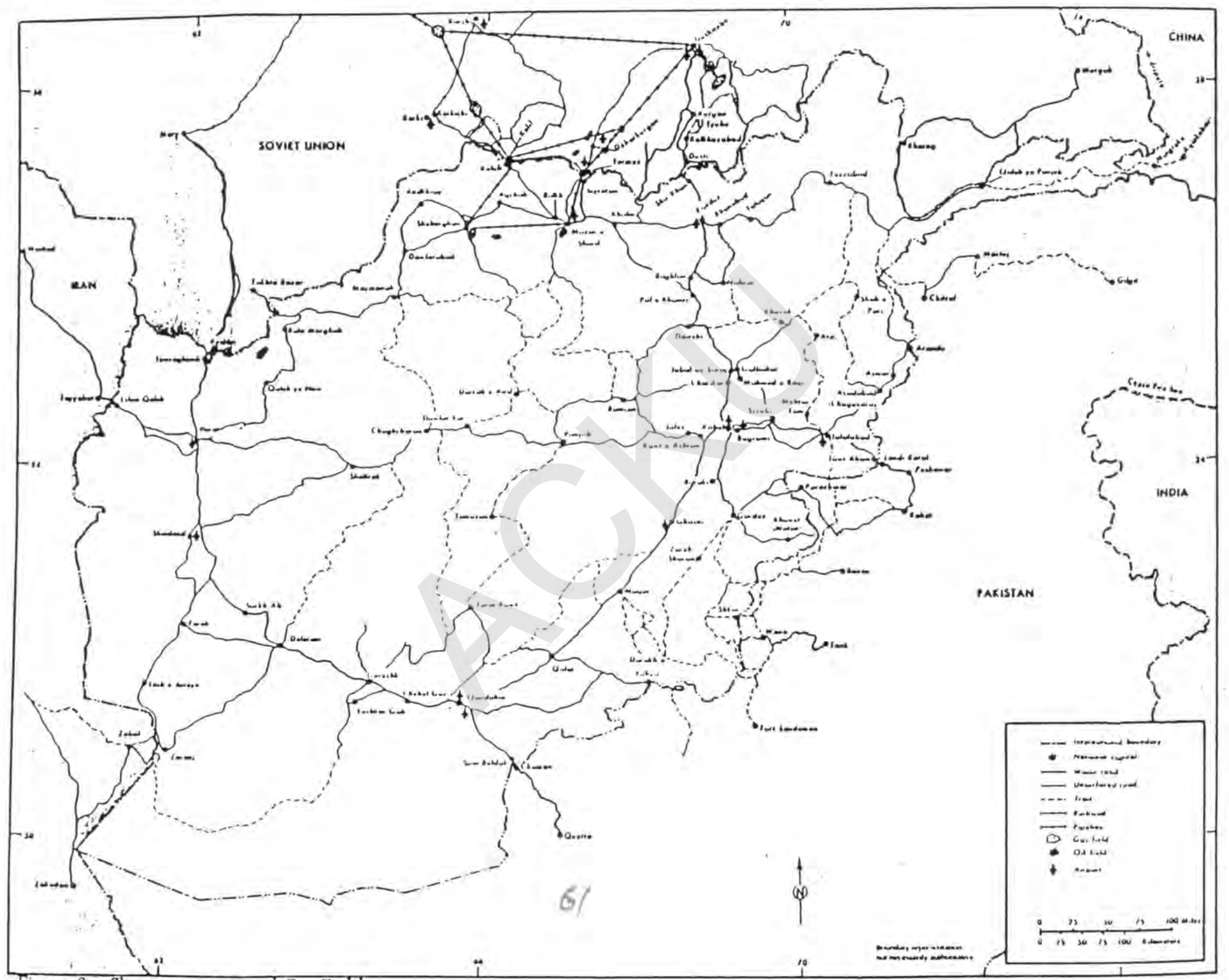

Figure 6. Transportation and Cas Fields 


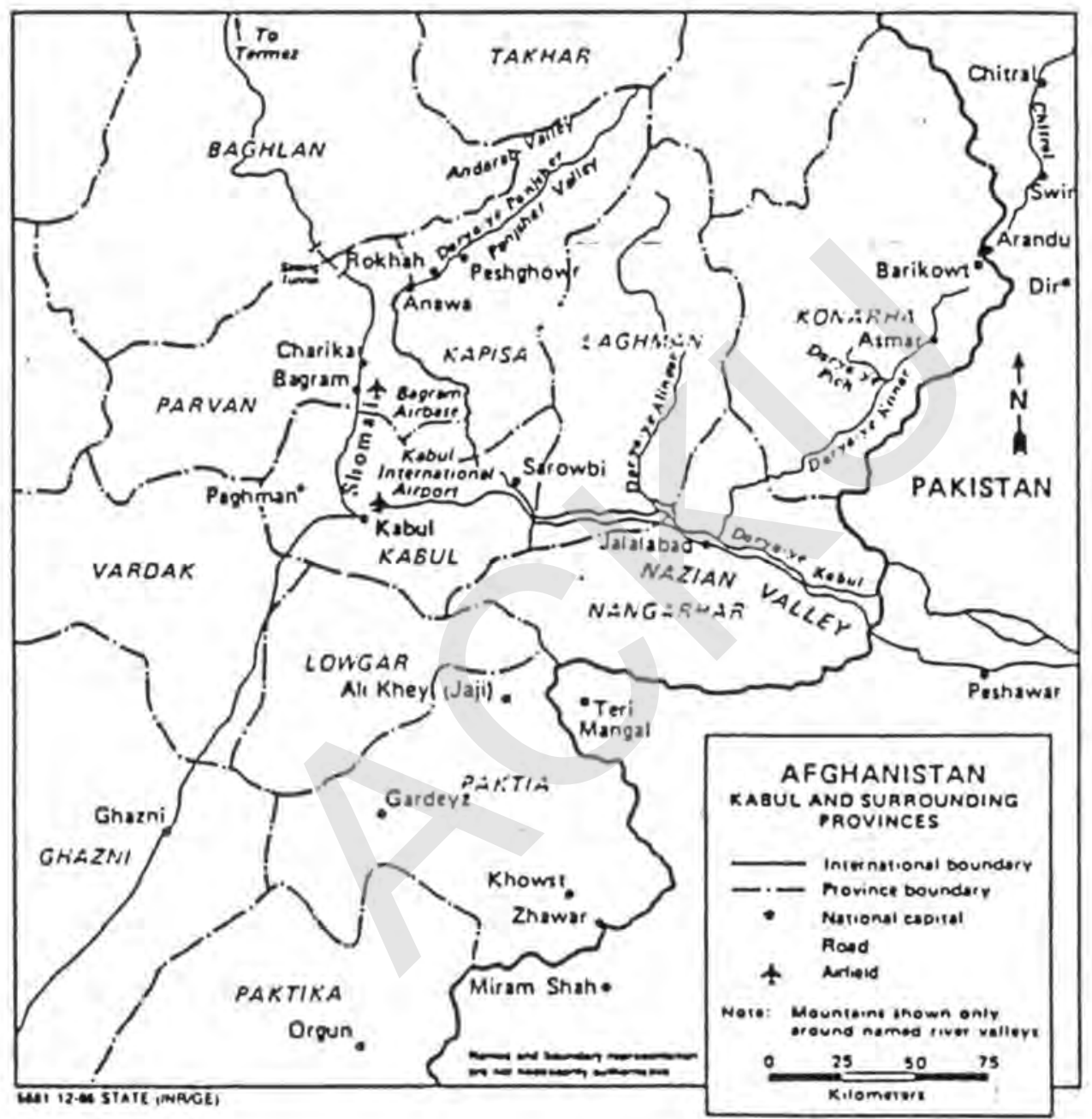

Source: U.S. Department of State 


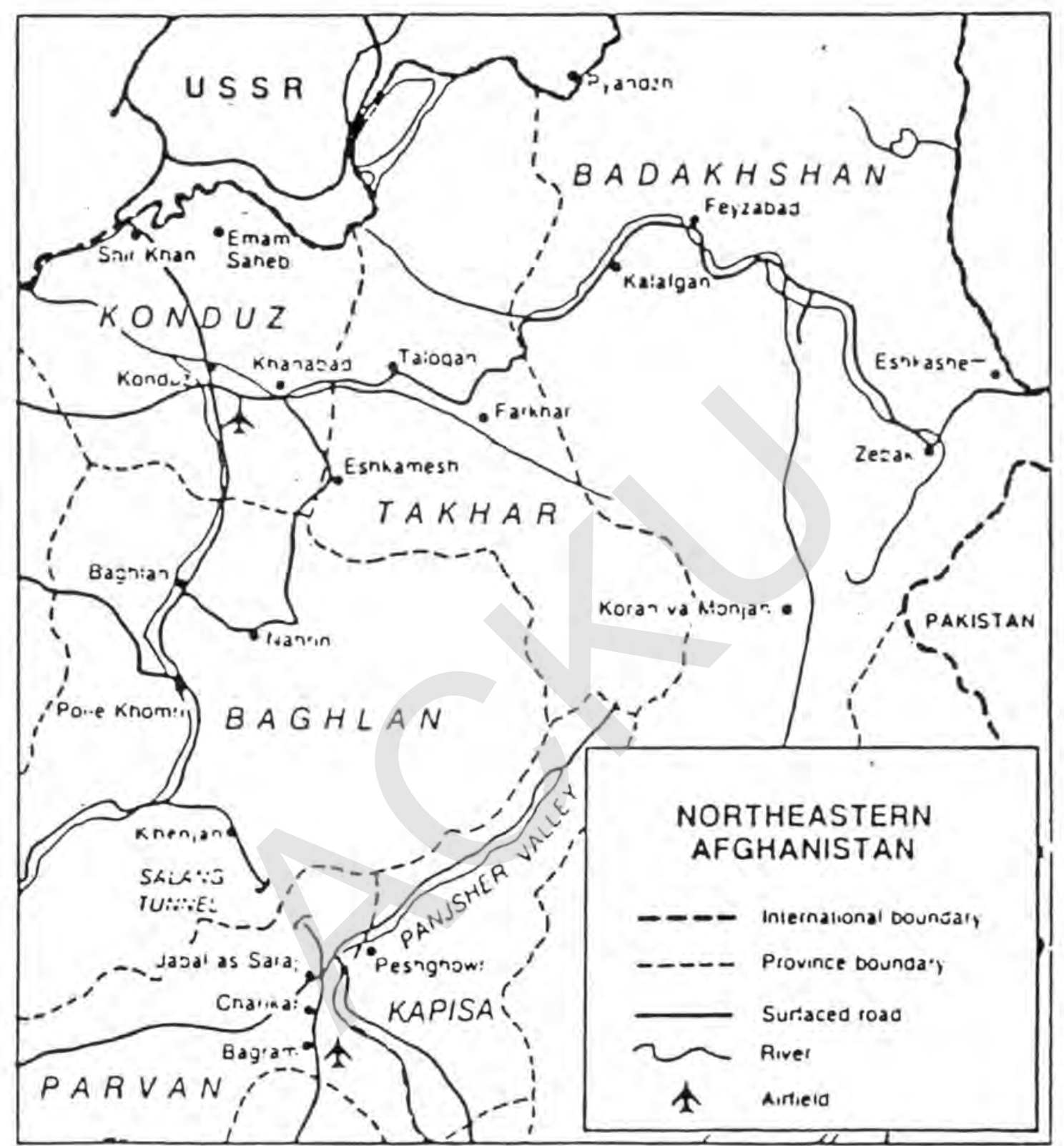

$6852128 \div 514 T C^{-11+A G E,}$

Source: U.S. Department of State 


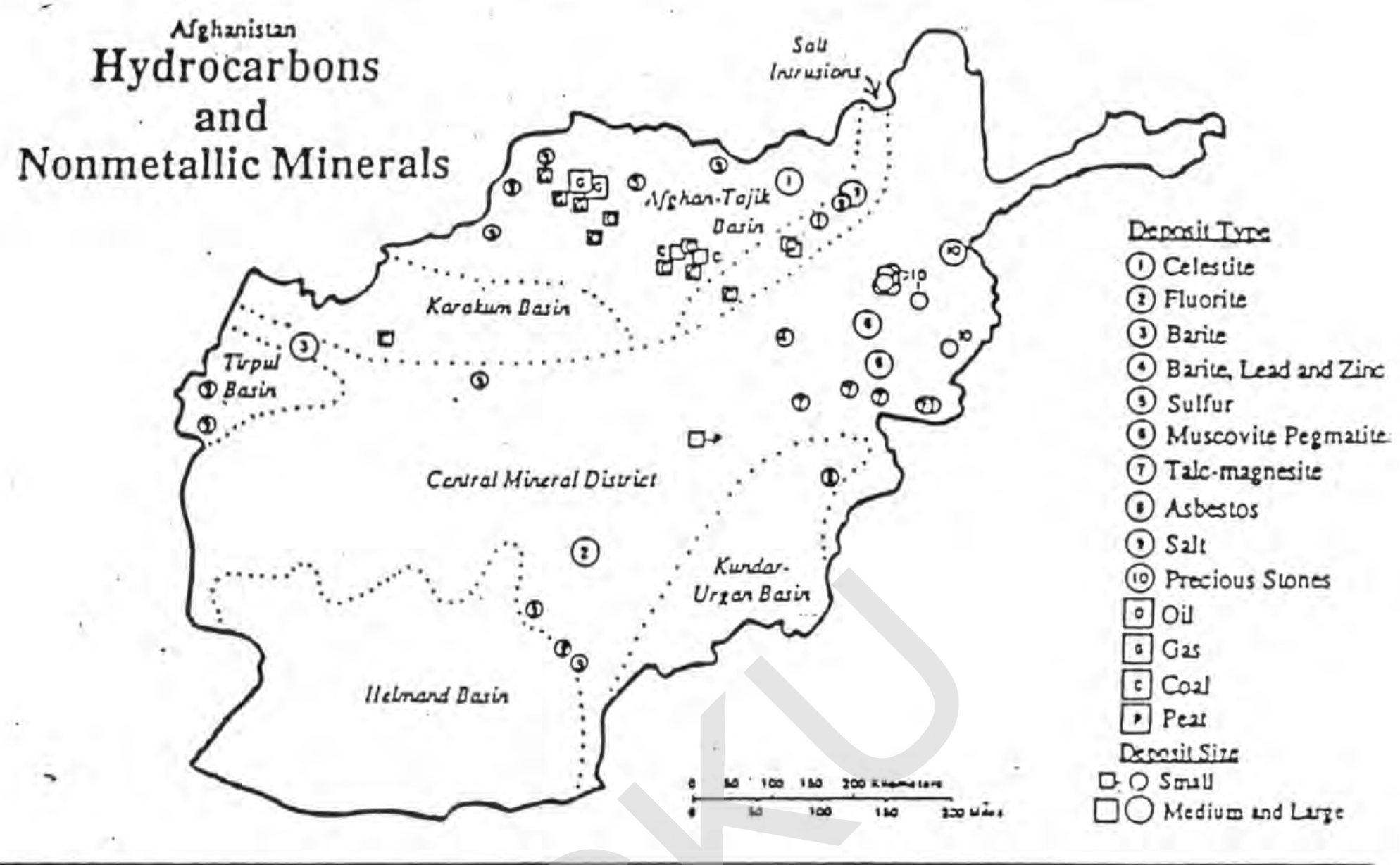

Source: Afghanistan: the Great Game Rev1sited 


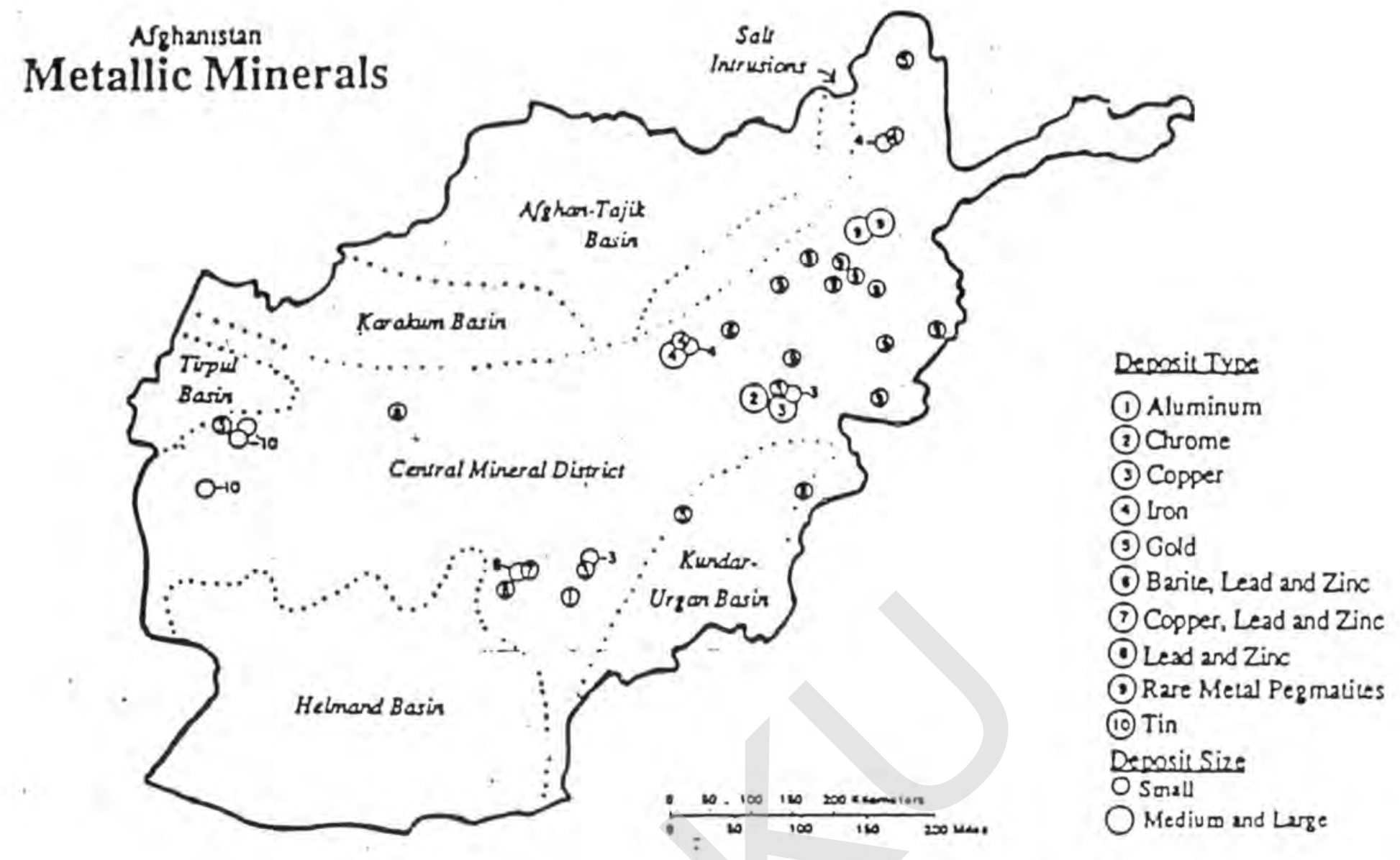




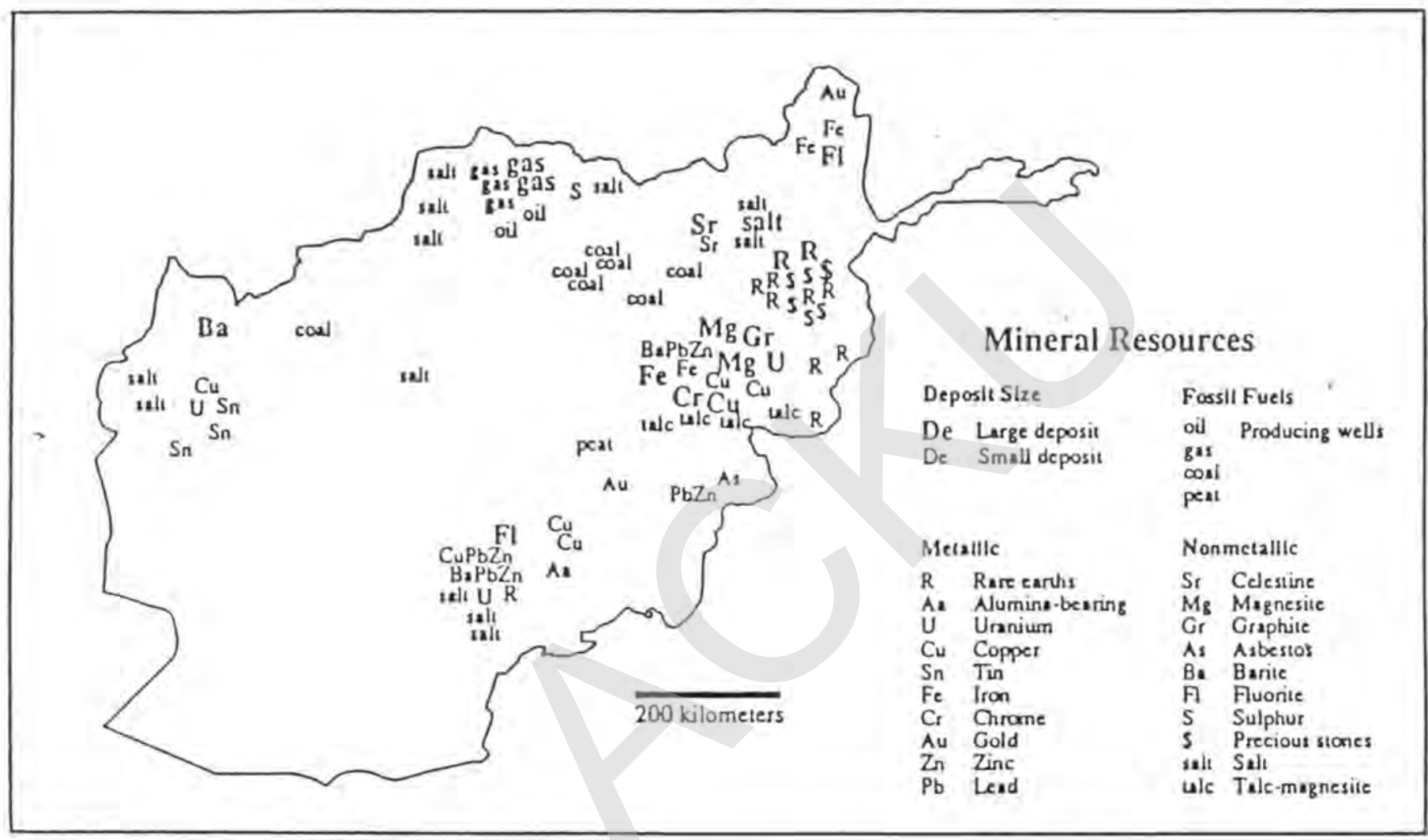

Map 6: Mineral Resources in Alghanistan 


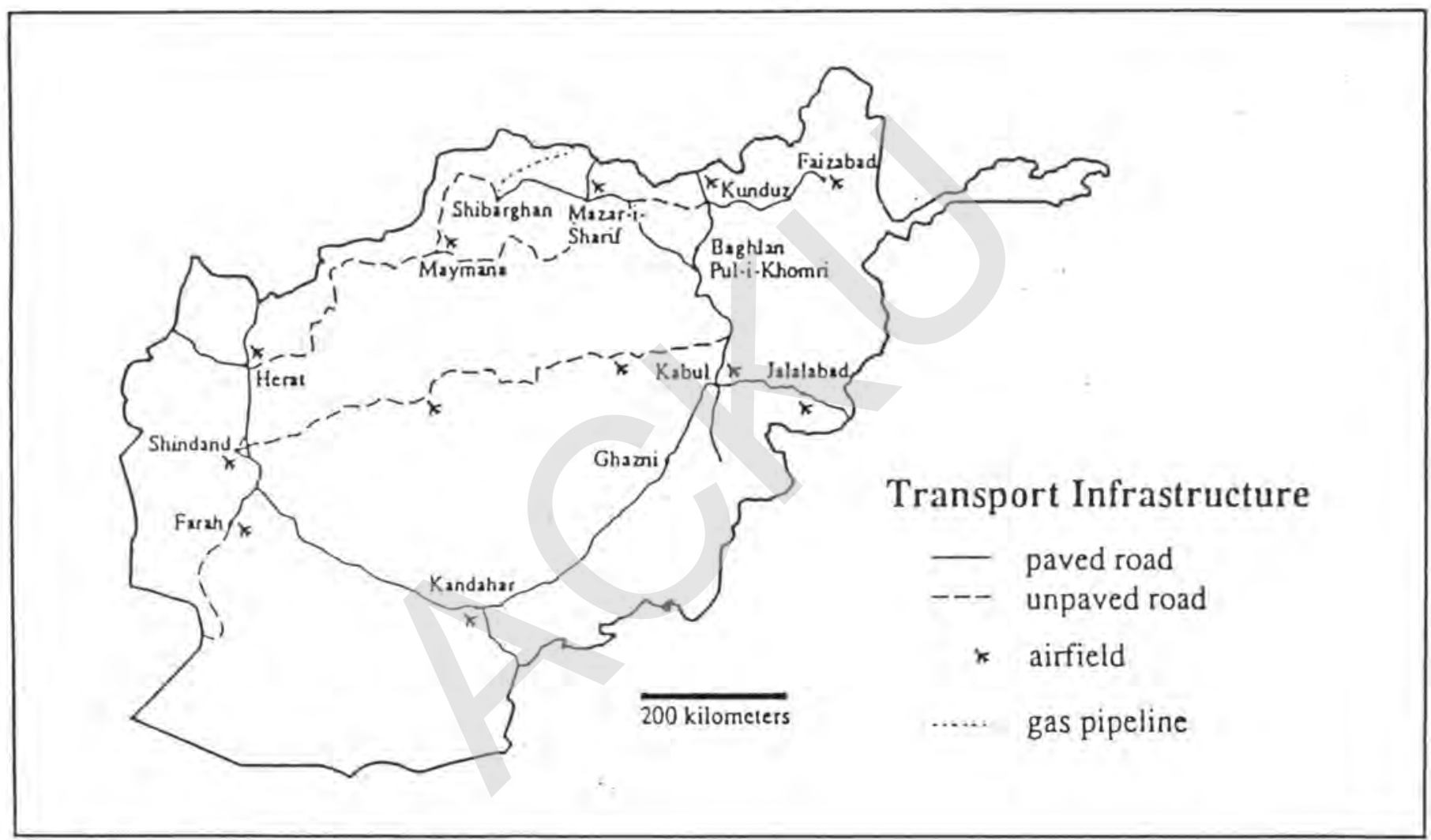

Map 5: Transport Infrasuructure in Afghanistan

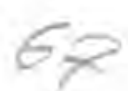



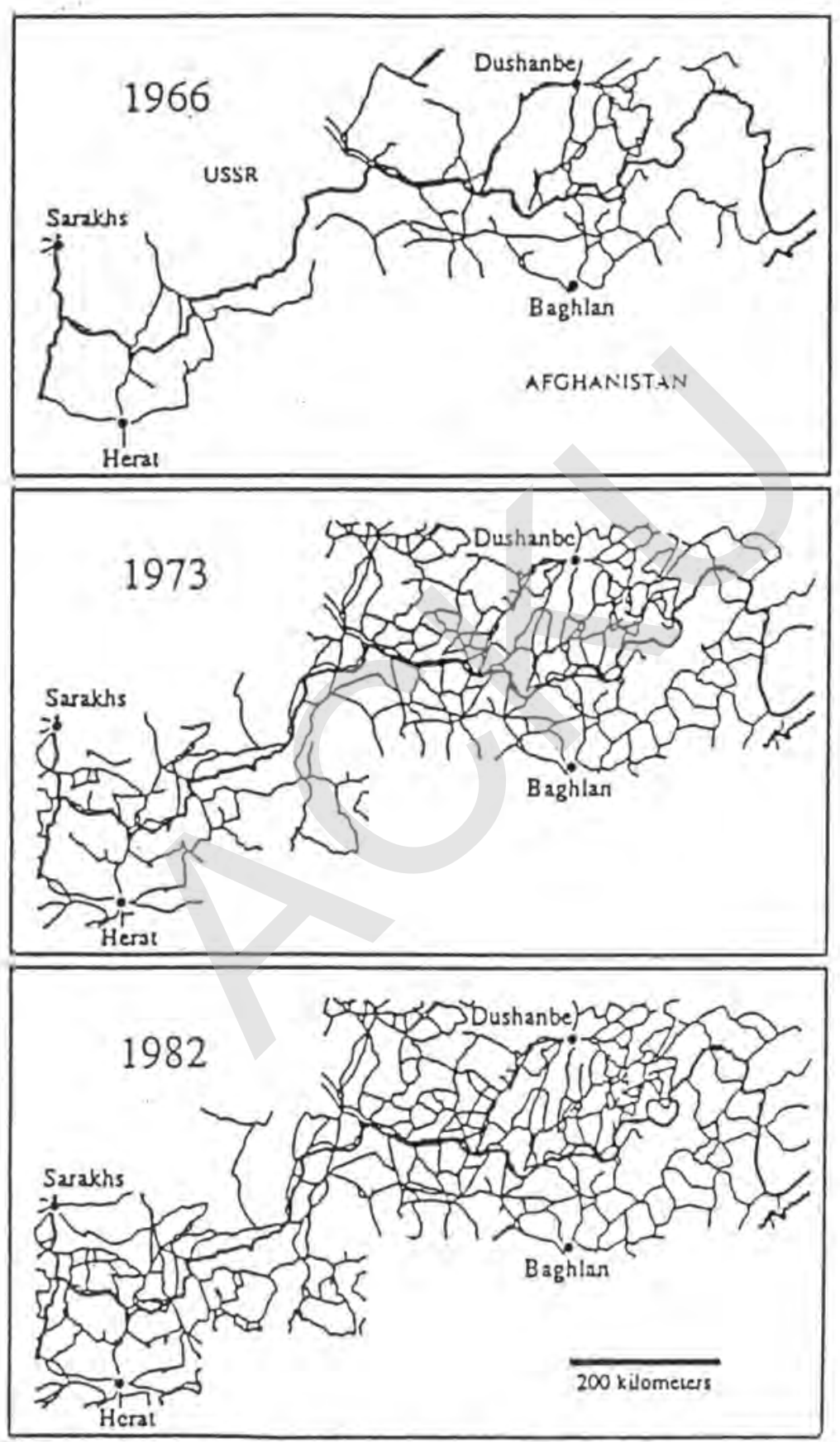

Map 7: The Development of Infrastrueture (Roads and Raif) on the Arghanistan-Sovict Border 


\section{Soviet Contracts}

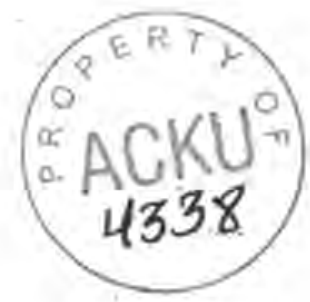

Afghan/Soviet agreements called for the export of 2.5 billion cubic meters of gas, on average, to the USSR up to the year 1985. (Any reduction of deliveries from Khwaja Gugirak was to be made up by adding in desulfurized gas from Jarquduq.) The revenues from the sale of the gas were not, however, to be returned to the Afghan government. They were to be applied as repayment for Soviet loans and the interest on those loans, including those spent by the Russians for Russian-assisted projects. The repayment of loans was detailed in Article 5 of the February 6, . 1968. Agrement for Economic and Titechnical Assistancel liticthe' years $1967-1972$ between the royal government of Afghanistan and the government of the USSR:

The repayment of the loans and the payments of interest on loans of Parts 2 and 3 of Article 2 of this agreement by the Royal Alghan Government with the export of natural gas and delivery of other Alghan goods from Afghanistan to the Soviet Union in accordance with the aceredited Afghan-Soviet Trade Agreement, shall be made as follows:

The quantity of natural gas and the kinds of other Alghan goods and their prices, quantities, and time of delivery for each calendar year, will be determined by the two sides three months before the beginning of the year of the repayment of the loan and the payment of Interest on the loan.

In the event the value of the natural gas delivered and other Afghan goods does not suffice for the repayment of the loans and interests coming to maturity during the calendar year, the remainder shall be paid in internationally exchangeable eurrencies of the eurrencies of each side at the exchange rates that will be established by the two sides in accordance with Article 13, Afghan-Soviet Trade and Payments Agreement dated July 17, 1950. The exchange of rubles to other eurrencies shall be done on the basis of the worth of that currency in gold, on the day of payment.

The expenses of Soviet institutions related to the technical assistanee of the construction of the projects mentioned in Part 3 of Article 1 of this agreement shall be paid by the export of natural gas and other Afghan goods with consideration to the contents of Part 4, Article 2 of this Agreement under the conditions of the accredited Afghan-Soviet trade agreement.

Although the 1968 Agreement spoke of prices "determined by the two sides," in practice the Soviet Union determined the price it would pay, and controlled all information regarding the amount of gas imported, the payment due Afghanistan, and other such details. In fact, the Soviet Union never paid Afghanistan more than twenty percent of the going world markel price for natural gas. 